\title{
THE EFFECT OF COMMERCIAL FEED SUPPLEMENTED WITH SELECTED YEAST, PROBIOTICS AND HERBAL ADDITIVES ON THE GROWTH PERFORMANCE OF JUVENILE DUSKY KOB (Argyrosomus japonicus)
}

\author{
Molatelo Junior Madibana*, Lucia Matlale Mbokane, Chris Henri Fouché \\ Department of Agriculture Forestry and Fisheries, Private Bag X2, Vlaeberg, 8018, South Africa \\ *Corresponding Author, Email: MolateloMA@daff.gov.za
}

ARTICLE INFO

Received: 5 April 2017

Received in revised form: 14 June 2017

Accepted: 10 July 2017

Available online: 2 October 2017

\begin{abstract}
The main objective of this investigation was to test the effect of a standard commercial feed (Skretting Active ZA) on the growth performance of juvenile dusky kob (Argyrosomus japonicus), compared to the same feed when supplemented with six commercially available additives over a period of 10 weeks. A common additive in trial treatments contained two yeast strains ( $84 \%$ Candida utilis and $16 \%$ Saccharomyces cerevisiae) that were incorporated at $33 \%$ of the total feed mass. The yeast combined diet was also tested per se as a base experimental diet (BED). In the remaining five trials the BED was respectively mixed with selected herbal extracts or pharmaceutical probiotics to comparatively measure possible superimposed growth enhancement. Herbal extracts were Aquapro (herbal powder), Liv-Up (herbal granule), Liv-Up (liquid) and UNBP$20^{\circ}$ (liquid). The pharmaceutical 2-strain probiotic was Probiflora (Lactobacillus acidophilus and Bifidobacterium bifidus). Experimental diets closely reflected comparative approximate nutrient values with respect to protein $(46-48 \%)$, carbohydrate $(17-18 \%)$, fat $(\sim 14 \%)$ and fibre (11$12 \%$ ) content. Juvenile dusky kob ( $n=50$ per tank) of about $5.77 \pm 1.28 \mathrm{~g}$ were experimentally grown for 10 weeks in tanks (465 L) of a suitable recirculating aquaculture system (RAS) $\left(24-25^{\circ} \mathrm{C}\right)$ with natural lighting. Supplement added diets induced a substantial average body growth of $43.3 \mathrm{~g}$, except for slower $(\mathrm{P}<0.05)$ growth measured for the Live-Up -liquid additive trial. The SGR was of the same magnitude between the BED and its complex with the mentioned additives. Also, the BED ( $46.5 \%$ protein) mediated a faster SGR $(P<0.05)$ than the control diet without yeast $(50 \%$ protein). The best FCR (0.95) was achieved with the BED added herbal product UN-BP20. The dietary inclusion of the inactivated yeast types is recommended for dusky kob commercial diets since it showed enhanced growth performance and possible production viability.
\end{abstract}

Madibana, M.J., Mbokane, L.M., Fouché, C.H. (2017): The effect of commercial feed supplemented with selected yeast, probiotics and herbal additives on the growth performance of juvenile dusky kob (Argyrosomus japonicus). Croatian Journal of Fisheries, 75, 160-166. DOI: 10.1515/cjf2017-0021 


\section{INTRODUCTION}

South Africa is considered a developing country and contributed minimally to total world aquaculture production output of about 66.6 million tons (FAO, 2016). South Africa is also known to be one of the leading countries in abalone production but marine finfish production is still underdeveloped (Troell et al., 2006). Dusky kob, or mulloway (Argyrosomus japonicus), is currently the preferred marine finfish species and is produced at commercial levels by four companies in South Africa. Dusky kob is capable of relatively fast growth rates with a good feed conversion ratio (FCR). It easily adapts to formulated feed and can grow well under intensive culture systems (Griffiths, 1996).

The growth of dusky kob intensive aquaculture industry in South Africa is limited by challenging production constraints such as production energy cost, as well as feed quality and cost (Shipton and Britz, 2007). Costs associated with feeds and feeding typically constitute the largest portion of operating expenses in the production of fish in intensive culture (El-Sayed, 1999; Fagbenro and Davies, 2001). The formulation of cost-effective, nutritionally optimal diets is therefore imperative to ensure profitability and reducing waste output on marine fish farms (Hilton et al., 1981; Farmanfarmaian et al., 1982; Pirozzi, 2009).

Woolley et al. (2009) developed a practical diet for juvenile dusky kob composed of $45 \%$ protein (fish meal) and $11 \%$ lipids (fish oil). The protein requirement for dusky kob was estimated at about 45-50\% (Pirozzi et al., 2010), a value that is similar to the requirement of the congeneric meagre (Argyrosomus regius) (Olim, 2012). Dusky kob has a limited capacity to spare dietary protein (Pirozzi et al., 2010). Research is therefore required to test the dietary inclusions for growth - immunostimulation - and appetitepromoting dietary additives in juvenile or grower dusky kob. Selected probiotic strains have been evaluated and were found to have beneficial potential for feed supplementation and enrichment in finfish aquaculture. These products include bacteria, microalgae and yeasts (Reyes-Becerril et al., 2008). These studies therefore indicate that probioticenriched feeds may be commercially beneficial to current and emergent finfish aquaculture industries in South Africa. Inactivated yeast is one of the ingredients that have been increasingly used in fish and shrimp feeds (Ozório et al., 2012; Castro et al., 3013). The inclusion of dried brewer's yeast (Saccharomyces cerevisiae) in global fish feed formulations has been increasing due to its digestibility and bioavailability, as well as prebiotic constituents (MOSmannan-oligosaccharides). A 25\% Torula yeast (Candida utilis) inclusion in tilapia (Oreochromis mossambicus) fry diets optimised growth performance (Olvera-Novoa et al., 2002).

There are also non-endocrine metabolic stimulants of herbal origin that enhance growth and/or immune function in fish (Abraham et al., 2000). Commercially available herbal stimulants are involved in physiological processes that increase intestinal absorption of nutrients, hepatic metabolic activity and cell function (Sing et al., 2009).

The current study was designed to:

a. Compare the growth performance of kob maintained on commercial feed (Skretting Active ZA) against 33\% replacement $(\mathrm{m}: \mathrm{m})$ thereof with combined inactivated yeast strains (84\% Candida utilis and 16\% Saccharomyces cerevisiae) during a period of 10 weeks;

b. Determine if there is any discerned SGR or FCR-promoting effect when two selected probiotic strains or four respective herbal complexes are added to the yeast added feed as prepared in objective a. The results will be a supportive step in eventually formulating an economic growth enhancing feed for the dusky kob industry.

\section{MATERIALS AND METHODS}

Experimental diet compositions: Fresh commercial (Skretting Active ZA) kob pellet (1-3 mm) was used untreated as control feed. Also, the pellets were powdered and combined with inactivated yeast in a ratio of 2:1 and mixed with cod liver oil and a multivitamin/mineral mix (Gerivet ${ }^{\circ}$ ), and used as the base experimental diet (BED). The BED was also combined with trial-specific selected dietary additives (Table 1) to test the effect thereof on the 10 -week growth rate of juvenile kob with an average initial body mass of $5.81 \mathrm{~g}$ (SD:1.25; SE: 0.18 ; $\mathrm{n}=1000$ ). The proximate condition of all experimental and control diets (as analysed) is summarised in Table 1.

Food preparation: Additive included diets were prepared as follows:

Skretting active ZA pellets $(2 \mathrm{~mm})$ were granulated $(<0.8$ $\mathrm{mm}$ ) with a Krups Burr Grinder GVX 2. The powdered pellets were selectively and proportionally mixed with the yeast types, multi-vitamins/minerals and trial-determined additives as shown in Table 1. The quantification of ingredients was approximately standardized by balancing the values for total protein, fat, carbohydrate and fibre content - using the control diet as reference.

Water was mixed with the final dry food at a ratio of 0.66 . The mixture was then kneaded to produce dough. The dough was rolled using a kitchen dough roller to create a thin layer onto a smooth plastic sheet as a clean surface. The plastic surface was firstly prepared by pressure spraying a non-stick agent (Cook'n Bake ${ }^{\circledR}$ ) that contains sunflower oil and lecithin. The thin layer of feed paste was then uniformly fan dried.

The flaked pieces of dried food were then graded to size by using a corn kernel hand grinder with adjustable pressure disc for flake sizing. Granule sizes were sieve graded (1.5 - 3 
$\mathrm{mm}$ ) and packed in plastic bags, and stored in a household refrigerator. Prior to fish feeding, the granules were mixed with cod liver oil at the calculated ration (Table 1). All experimental fish groups were consistently fed at $2.8 \%$ body mass per day as adjusted and calculated on a weekly basis after sampling.

\section{Experimental fish and sampling}

Handling of live fish was conducted in compliance with the South African Animals Protection Act, 1962 (Act 71 of 1962). Juvenile dusky kob of the same cohort with an average initial body mass of $5.81 \mathrm{~g}(\mathrm{SD}: 1.25$; SE: $0.18 ; \mathrm{n}=1000)$ were

Table 1. Ingredients and analysed chemical composition of the seven trial diets

\begin{tabular}{|c|c|c|c|c|c|c|c|}
\hline & & & $\begin{array}{l}\text { Experimental } \\
\text { diets }\end{array}$ & & & & \\
\hline Ingredient & $\begin{array}{l}\text { Aquapro } \\
\text { premix }\end{array}$ & $\begin{array}{l}\text { Liv Up } \\
\text { granules }\end{array}$ & Liv Up" liquid & $\begin{array}{l}\text { UNP } \\
\text { PB-20 }\end{array}$ & Probiflora & $\begin{array}{l}\text { Base } \\
\text { Experimental } \\
\text { Diet (BED) }\end{array}$ & $\begin{array}{l}\text { Skretting } \\
\text { Active ZA }\end{array}$ \\
\hline Skretting Active $\mathrm{ZA}^{\circledR}$ pellet (g) & 628.9 & 628.9 & 628.9 & 628.9 & 628.9 & 636.6 & 1000.0 \\
\hline Torula yeast (g) & 258.9 & 258.9 & 258.9 & 258.9 & 258.9 & 262.1 & 0.0 \\
\hline Brewer's yeast $(\mathrm{g})$ & 51.8 & 51.8 & 51.8 & 51.8 & 51.8 & 52.4 & 0.0 \\
\hline $\begin{array}{l}\text { Aquapro Premix herbal } \\
\text { stimulant }(\mathrm{g})\end{array}$ & 10.4 & 0.0 & 0.0 & 0.0 & 0.0 & 0.0 & 0.0 \\
\hline $\begin{array}{l}\text { Liv-up herbal extract } \\
\text { granules }(\mathrm{g})\end{array}$ & 0.0 & 10.4 & 0.0 & 0.0 & 0.0 & 0.0 & 0.0 \\
\hline $\begin{array}{l}\text { Liv-up herbal extract liquid } \\
(\mathrm{ml})\end{array}$ & 0.0 & 0.0 & 103.6 & 0.0 & 0.0 & 0.0 & 0.0 \\
\hline $\begin{array}{l}\text { UNP PB- } 20^{\circ} \text { herbal extract } \\
\text { liquid }(\mathrm{ml})\end{array}$ & 0.0 & 0.0 & 0.0 & 103.6 & 0.0 & 0.0 & 0.0 \\
\hline Probiflora 2-strain ${ }^{\circ}(\mathrm{g})$ & 0.0 & 0.0 & 0.0 & 0.0 & 10.4 & 0.0 & 0.0 \\
\hline Gerivet $^{\circ}$ (Min/vit mix) (g) & 3.6 & 3.6 & 3.6 & 3.6 & 3.6 & 3.5 & 0.0 \\
\hline Cod liver oil (ml) & 46.4 & 46.4 & 46.4 & 46.4 & 46.4 & 45.5 & 0.0 \\
\hline Water (ml) & 629.2 & 629.2 & 639.4 & 639.4 & 629.2 & 630.0 & 0.0 \\
\hline \multicolumn{8}{|l|}{ Composition $\left(\mathrm{g} \mathrm{kg}^{-1}\right)$} \\
\hline Dry matter & 917.7 & 912.1 & 910.2 & 933.8 & 914.3 & 904.1 & 931.0 \\
\hline Organic matter & 796.7 & 810.1 & 803.2 & 818.8 & 804.3 & 805.1 & 826.0 \\
\hline Crude protein & 473.7 & 469.0 & 471.4 & 495.0 & 475.0 & 465.3 & 500.0 \\
\hline Fat & 140.1 & 140.4 & 141.3 & 141.3 & 140.5 & 140.2 & 140.0 \\
\hline Carbohydrates & 170.9 & 188.8 & 179.1 & 171.1 & 177.3 & 188.2 & 168.0 \\
\hline Crude Fibre & 12.0 & 11.9 & 11.4 & 11.4 & 11.5 & 11.4 & 18.0 \\
\hline Moisture & 82.3 & 87.9 & 89.8 & 66.2 & 85.7 & 95.9 & 69.0 \\
\hline Ash & 121.0 & 102.0 & 107.0 & 115.0 & 110.0 & 99.0 & 105.0 \\
\hline
\end{tabular}


produced at the Marine Research Aquarium (Seapoint, Cape Town, South Africa) and 50 individuals randomly removed and transferred to a system keeping tank (20 tanks in total). Six test trials were conducted in triplicate, whilst the control trial (Skretting Active ZA) was conducted in two respective tanks due to limited tank availability. All the fingerlings were fed with commercial kob feed (Skretting Active ZA $=50 \%$ protein) prior to the onset of the experiment. The fish were not exposed to any light to minimize cannibalistic behaviour. Fish were fed manually twice a day and with equal ration portions respectively in the morning (08:30) and afternoon (15:30). Ten fish from each of the twenty tanks were randomly sampled and anaesthetised (2-phenoxyethanol at $0.2 \mathrm{ml} \mathrm{L}^{-}$) once a week and the caudal length and body mass (Mettler Toledo electronic balance model: Viper SW 15) of each individual was recorded to determine the SGR, FCR, condition factor (CF), as well as ration adjustment per trial for the next week. The formulas as described by Trushenski et al. (2006) were employed to calculate the SGR and FCR. Tanks were daily monitored for any mortalities and fish behavioural changes before or during feedings.

Fish keeping system design: An automated twenty tank recirculating aquaculture nursery system ( $10 \mathrm{~kL}$ ) was used to keep all experimental fish consistently at optimal water quality and temperature $\left(24-26^{\circ} \mathrm{C}\right)$. The system's tanks (465 L) were made of black high-density polyethylene with white floors (white fiberglass resin coating) as background to mediate contrast for fish visibility. The cylindroconical (flat) system tanks were $67 \mathrm{~cm}$ deep (water) and $94 \mathrm{~cm}$ in diameter. The tanks were covered with $6 \mathrm{~mm}$ mesh "bird eye netting" to facilitate feeding and to prevent jumping fish from escaping.

\section{Water quality parameters}

The temperature, oxygen and carbon dioxide values were daily monitored with a calibrated Oxyguard ${ }^{\circ}$ handheld apparatus. The $\mathrm{pH}$, ammonia, nitrate, nitrite was colorimetrically determined twice a week with disposable strip tests supplied by $\mathrm{HACH}^{\circ}$. All water quality parameters were at acceptable levels for optimal fish keeping.

Statistical analyses: Apart from Normality and Equal Variance tests, a one-way ANOVA was used to validate any collective parameter value differences between trials or

Table 2. Weekly juvenile kob growth performance in grams per respective diet treatments during the experimental period of 10 weeks (Mean \pm SE)

Experimental Diets

\begin{tabular}{|c|c|c|c|c|c|c|c|}
\hline & $\begin{array}{l}\text { Aquapro } \\
\text { Premix }\end{array}$ & $\begin{array}{l}\text { Liv Up } \\
\text { granules }\end{array}$ & Liv Up liquid & UNP BP- $20^{\circ}$ & Probiflora & $\begin{array}{l}\text { Base } \\
\text { Experimental } \\
\text { Diet (BED) }\end{array}$ & $\begin{array}{l}\text { Skretting } \\
\text { Active ZA } \\
\text { (control) }\end{array}$ \\
\hline \multicolumn{8}{|c|}{ Weeks } \\
\hline 0 & $8.05 \pm 0.59^{a}$ & $9.05 \pm 0.44^{\mathrm{a}}$ & $8.75 \pm 0.47^{a}$ & $8.27 \pm 0.36^{a}$ & $8.64 \pm 0.34^{a}$ & $8.67 \pm 0.42^{\mathrm{a}}$ & $7.60 \pm 0.71^{\mathrm{a}}$ \\
\hline 1 & $10.66 \pm 0.28^{b}$ & $10.29 \pm 0.25^{b}$ & $10.34 \pm 0.35^{b}$ & $11.47 \pm 0.55^{b}$ & $11.24 \pm 0.83^{b}$ & $11.57 \pm 0.21^{b}$ & $8.23 \pm 0.41^{\mathrm{a}}$ \\
\hline 2 & $13.81 \pm 0.70^{b}$ & $14.10 \pm 0.13^{a}$ & $12.77 \pm 1.20^{\mathrm{ab}}$ & $14.50 \pm 0.17^{b}$ & $14.16 \pm 1.07^{b}$ & $14.42 \pm 0.68^{b}$ & $10.72 \pm 0.21^{\mathrm{a}}$ \\
\hline 3 & $17.70 \pm 1.01^{c}$ & $17.63 \pm 1.04^{c}$ & $14.03 \pm 1.92^{\mathrm{ab}}$ & $16.77 \pm 0.48^{\mathrm{bc}}$ & $17.20 \pm 0.35^{b c}$ & $19.27 \pm 0.32^{c}$ & $11.10 \pm 0.40^{\mathrm{a}}$ \\
\hline 4 & $22.90 \pm 1.22^{\mathrm{b}}$ & $22.40 \pm 1.90^{\mathrm{b}}$ & $15.43 \pm 1.94^{\mathrm{a}}$ & $19.87 \pm 1.19^{b}$ & $20.43 \pm 0.74^{b}$ & $24.13 \pm 0.34^{b}$ & $11.65 \pm 0.75^{\mathrm{a}}$ \\
\hline 5 & $28.10 \pm 1.55^{\text {cde }}$ & $29.48 \pm 2.51^{\text {de }}$ & $17.78 \pm 2.41^{b}$ & $23.31 \pm 0.70^{c}$ & $25.55 \pm 0.45^{c d}$ & $32.16 \pm 2.14^{e}$ & $11.61 \pm 0.10^{\mathrm{a}}$ \\
\hline 6 & $33.65 \pm 1.17^{c d}$ & $40.41 \pm 4.10^{\mathrm{e}}$ & $20.68 \pm 1.52^{\mathrm{b}}$ & $28.84 \pm 1.55^{c d}$ & $27.45 \pm 1.47^{c}$ & $34.84 \pm 0.49^{\mathrm{de}}$ & $13.52 \pm 0.11^{\mathrm{a}}$ \\
\hline 7 & $40.43 \pm 3.98^{\mathrm{d}}$ & $41.67 \pm 0.99^{d}$ & $23.89 \pm 2.69^{b}$ & $29.90 \pm 3.31^{b c}$ & $36.87 \pm 1.29^{c d}$ & $38.87 \pm 1.07^{d}$ & $11.85 \pm 1.15^{\mathrm{a}}$ \\
\hline 8 & $41.65 \pm 3.77^{d}$ & $43.97 \pm 1.21^{d}$ & $24.83 \pm 1.03^{b}$ & $31.57 \pm 3.13^{c}$ & $38.17 \pm 1.47^{d}$ & $40.53 \pm 1.37^{d}$ & $12.37 \pm 0.63^{\mathrm{a}}$ \\
\hline 9 & $44.07 \pm 0.70^{d}$ & $43.76 \pm 4.32^{\mathrm{d}}$ & $25.28 \pm 2.45^{b}$ & $33.47 \pm 2.15^{c}$ & $41.82 \pm 1.94^{d}$ & $43.18 \pm 2.18^{d}$ & $12.66 \pm 0.26^{a}$ \\
\hline 10 & $48.23 \pm 2.39^{c}$ & $49.39 \pm 5.27^{c}$ & $27.99 \pm 3.46^{b}$ & $46.84 \pm 1.66^{c}$ & $48.99 \pm 1.37^{c}$ & $52.05 \pm 2.13^{c}$ & $11.98 \pm 0.10^{\mathrm{a}}$ \\
\hline FCR & $1.03^{a}$ & $1.08^{a}$ & $1.36^{\mathrm{b}}$ & $0.92^{a}$ & $0.95^{a}$ & $0.99^{a}$ & $1.01^{\mathrm{a}}$ \\
\hline
\end{tabular}

Significant $(\mathrm{P}<0.05)$ differences among means in the same row are indicated by different superscripts 
intra-triplicate population groups. The Tukey's post-hoc test was used for paired and multiple comparisons - with a statistical differential probability of $p \leq 0.05$ considered as significant. Statistical analysis was performed with SPSS 11.5 statistical package (IBM Corporation, Armonk, New York, USA).

\section{RESULTS}

There was no difference in juvenile kob growth rates when fed with test diets (Aquapro Premix ${ }^{\circ}$, Liv Up granules, UNP PB-20, Probiflora and BED) during the experimental period of 10 weeks. Table 2 illustrates weekly fish growth performance per respective dietary treatment. There were also no inter-population growth rate differences within all triplicate groups per test diet. The average body weight gain of the BED fed group after 10 weeks was $46.2 \mathrm{~g}$, which was superior amongst all dietary treatments. The Live Up liquid diet and control respectively produced the least body weight gain of $22.0 \mathrm{~g}$ and $35.0 \mathrm{~g}$.

Juveniles fed the Liv Up liquid diet grew significantly slower from week four when compared to the test and control diets. Condition factor of all experimental and control groups were consistent $(C \sim 1.7)$. The FCR for the respective test diets is indicated in Table 2 . The lowest mean FCR (0.92) was determined for test UNP PB-20 diet and the highest for test Liv Up liquid diet (1.36). The feeding behaviour of fish in all treatment groups was generally consistent in terms of appetite and swimming behaviour.

\section{DISCUSSION}

Diets were equivalent in terms of their protein, carbohydrate and fat contents and conformed to the minimum required for optimized growth in dusky kob (Woolley, 2009; Rossetti, 2011). The SGR of control feed fed fish was less than for the BED. It is evident that the inactivated yeast portion (33\%) of the BED mainly contributed to improved growth performance since the yeast strains are highly digestible and also contained prebiotics (MOS) that likely enhanced digestibility with concomitant increased bioavailability and intestinal uptake of nutrients (Brownawell et al., 2012; Olvera-Novoa et al., 2002). Fish fed BED alone also attained the highest mean body weight ( $52 \mathrm{~g} \pm 2.13$ ) of all trial treatments tested. It has been reported that torula yeast enhanced growth in tilapia at a dietary inclusion of $30 \%$ (Olvera-Novoa et al., 2002) and brewer's yeast significantly enhanced sea bass (Dicentrarchus labrax) growth at 10-30\% dietary inclusion levels (Metailler and Huelvan, 1993). A lower level of $1-2 \%$ also enhanced growth performance in hybrid striped bass (Morone chrysops $\times$ M. saxatilis) after seven weeks of feeding.
Growth between the BED trial and its respective herbal and probiotic stimulant inclusions were similar - confirming the predominance in the growth inducing competency of the two combined inactivated yeast strains (Candida utilis: Saccharomyces cerevisiae).

The conspicuously lowered growth performance of fish fed Live-Up liquid diet is probably a function of antinutritional factors in the Live-up liquid formula since the rest of the diet composition was similar to the BED diet. Retrospectively, no such antinutritional factors were present in the Live-Up ${ }^{\circledR}$ granulated herbal product, since it induced a more similar SGR than for BED diet. One or more of the different incorporated herbal species within the Live-Up liquid composition could, therefore, be growth-inhibiting. The UN-BP20 $0^{\circ}$ fed group mediated the best FCR (0.92) of all experimental treatments. This plant-based diet also increased the total protein content to the highest value $(49.5 \%)$ of all test diets (Table 1 ) and may also partially substitute expensive animal protein in future diet formulations. Further research is required to validate the maximal and economic dietary inclusion rate for UN-BP20 .

The FCR (0.95) of the probiotic included diet also performed better than for the BED (FCR $=0.99)$. The probiotic microbes (Bifidiobacterium longum and/ or Lactobacillus rhamnosus) probably promoted the digestion and intestinal absorption of dietary nutrients due to the presence of prebiotics such as the MOScontaining cell walls of the used yeast strains. The FCR values of the respective Aquapro and Live-Up ${ }^{\circ}$ granule test diet additives were slightly higher $(1<$ value $<1.04$ ) than for the BED diet $(F C R=0.99)$. Further research is warranted to measure the effects of these herbal stimulants in increased dietary portions by also excluding the addition of yeast.

It is recommended that the tested inactivated yeast strains be incorporated in future cost-effective dusky kob diets. Also, the UN-BP $20^{\circledR}$, probiotics and yeast components could provide benefit. Follow-up trials will, however, be needed to measure possible synergistic effects thereof in improving the FCR and/or SGR of test fish.

\section{ACKNOWLEDGEMENTS:}

The authors firstly would wish to thank the DAFF sea point, Cape Town staff for material support and fish husbandry. Secondly, a special thanks to Mr Larry Dolley and Mr Ndumiso Mshicileli at Agrifood Technology station of Cape Peninsula University of Technology; Prof. Victor Mlambo and Mr Kenny Mnisi of North West University for their assistance with proximate analysis of the experimental diets. 


\section{Sažetak}

\section{UTJECAJKOMERCIJALNEHRANEDOPUNJENE ODABRANIM KVASCIMA, PROBIOTICIMA I BILJNIM ADITIVIMA NA RAST MLADOG Argyrosomus japonicas}

Glavni cilj ovog istraživanja je testirati učinak standardne komercijalne hrane (Skretting Active ZA) na rast mladog Argyrosomus japonicas u usporedbi $\mathrm{s}$ istom hranom dopunjenom sa šest komercijalno dostupnih aditiva kroz period od 10 tjedana. Zajednički dodatak tretmanima sastojao se od dva soja kvasaca ( $84 \%$ Candida utilis i 16\% Saccharomyces cervesiae) te je činio 33\% ukupne mase hrane. Hranidba kvascima testirana je i per se kao bazna eksperimentalna hrana (Base experimental diet - BED). U ostalih pet eksperimentalnih ispitivanja, BED je miješan $s$ odabranim biljnim ekstraktima ili farmaceutskim probioticima kako bi se usporedno mjerilo povećanje preklapajućeg rasta. Korišteni biljni ekstrakti su Aquapro (biljni prah), Liv-Up (biljne granule) i UNBP-20 (tekučina). Korišten je dvosojni probiotik Probiflora (Lactobacillus acidophilus i Bifidobacterium bifidus). Eksperimentalna hranidba usko je odražavala približne hranjive vrijednosti sadržaja proteina (46-48\%), ugljikohidrata (17-18\%), masnoća ( 14\%) te vlakana (11-12\%). Mladi Argyrosomus japonicas ( $\mathrm{n}=50$ po akvariju) od približno $5,77 \pm 1,28 \mathrm{~g}$ eksperimentalno su uzgajani u akvarijima ( $465 \mathrm{~L}$ ) odgovarajućeg recirkulacijskog akvakulturnog sustava (RAS) $\left(24-25^{\circ} \mathrm{C}\right)$ tijekom 10 tjedana, na prirodnoj svjetlosti. Nadopuna hranidbi inducirala je značajan prosječni rast tijela od 43,3 g, osim sporijeg rasta $(\mathrm{P}<0,05)$ izmjerenog kod riba hranjenim nadopunom tekućeg aditiva Liv-Up'. Stopa održivog rasta jednaka je između BED i kompleksa s već spomenutim aditivima. Isto tako je BED (46,5\% proteina) uzrokovao pojačanu stopu održivog rasta $(\mathrm{P}<0,05)$ pri usporedbi s kontrolnom hranidbom bez kvasaca (50\% proteina). Najbolji FCR $(0,95)$ postignut je s BED-om kojem je dodan biljni proizvod UNBP-20 $0^{\circ}$. Dodatak neaktivnih sojeva kvasaca preporuča se u komercijalnoj prehrani Argyrosomus japonicas, obzirom da uzrokuje pojačanu stopu rasta i moguću proizvodnu održivost.

Ključne riječi: akvakultura, Saccharomyces cerevisiae, Candida utilis, prehrambeni biljni stimulansi

\section{REFERENCES}

Abraham, S., Ramesha, T. J., Gangadharaand, B., Varghese, T. J. (2000): Growth response of common carp Cyprinus carpio (Linn) to varied levels of Livol, a nonhormonal growth promoter. Indian Journal of Fisheries, 48, 397 4018.

Brownawell, A. M., Caers, W., Gibson, G. R., Kendall, C. W.
C., Lewis, K. D., Ringel, Y., Slavin, J. L. (2012): Prebiotics and the Health Benefits of Fiber: Current Regulatory Status, Future Research, and Goals. The Journal of Nutrition, 142, 962 - 974.

Castro, C., Pérez-Jiménez, A., Coutinho, F., Pousão-Ferreira, D. P., Brandão, T.M., Oliva-Teles, A., Peres, H. (2013): Digestive enzymes of Meagre Argyrosomus regius and White seabream Diplodus sargus. Effects of dietary brewer's spent. Aquaculture, 416 - 417. 322 - 327.

El-Sayed, A. F. M. (1999): Alternative dietary protein sources for farmed tilapia, Oreochromis spp. Aquaculture, 179, 149 - 168.

Fagbenro, O. A., Davies, S. J. (2001): Use of soybean flour dehulled, solvent-extracted soybean as a fish meal substitute in practical diets for African catfish, Clarias gariepinus (Burchell 1822): growth, feed utilization and digestibility. Journal of Applied Ichthyology, 17, 64 - 69.

FAO, (2016): The State of World Fisheries and Aquaculture 20161 : Contributing to food security and nutrition for all' Food and Agriculture Organization of the United Nations (UN FAO), Rome. 200 pp. http://www.fao.org/3/ a-i5555e.pdf

Farmanfarmaian, A., Lauterio, T., Ibe, M., 1982. Improvement of the stability of commercial feed pellets for the giant shrimp, Macrobrachium rosenbergii. Aquaculture, 27, $29-41$.

Griffiths, M. H., 1996. Life history of the dusky kob Argyrosomus japonicus (Sciaenidae) off the coast of South Africa. South African Journal of Marine Science, 17, 135154.

Hilton, J. W., Cho, C. Y., Slinger, S. J. (1981): Effect of extrusion processing and steam pelleting diets on pellet durability, pellet water absorption, and the physiological response of rainbow trout, Salmo gairdneri . Aquaculture, 25, 185 - 194.

Metailler, R., Huelvan, C. (1993): Utilisation de levures dans l'alimentation du juvenile de bar (Dicentrarchus labrax). In: Fish Nutrition in Practice. Ed. INRA, Les Colloques, $61,945-948$.

Olvera-Novoa, M. A., Martínez-Palacios, C. A., OliveraCastillo, L. (2002): Utilization of torula yeast, Candida utilis as a protein source in diets for tilapia, Oreochromis mossambicus (Peters, 1852) fry. Aquaculture Nutrition, 8, $257-264$.

Ozório, R. O. A., Portz, L., Borghesi, R., Cyrino, J. E. P. (2012): Effects of dietary deast, Saccharomyces cerevisia Supplementation in practical diets of tilapia, Oreochromis niloticus. Animals, 2, 16 - 24.

Pirozzi, I. (2009): A factorial approach to defining the dietary protein and energy requirements of mulloway, Argyrosomus japonicus: optimizing feed formulations and feeding strategies. PhD thesis, James Cook University, 206pp.

Pirozzi, I., Booth, M. A., Allan, G. L. (2010): The interactive ef- 
fects of dietary protein and energy on feed intake, growth and protein utilization of juvenile mulloway Argyrosomus japonicus. Aquaculture Nutrition, 16, 61 - 7.

Reyes-Becerril, M., Tovar-Ramirez, D., Ascencio-Valle, F., Civera-Cerecedo, R., Gracia-Lopez, V., Barbosa-Solomieu, V. (2008): Effects of dietary live yeast, Debaryomyces hansenii on the immune and antioxidant system in juvenile leopard grouper, Mycteroperca rosacea exposed to stress. Aquaculture, 280, 39 - 44.

Rossetti, N. A. (2011): The effect of dietary fish oil replacement with soybean oil on growth and health of dusky kob, Argyrosomus japonicus Pisces: Sciaenidae. M. Sc. thesis, Department of Ichthyology and Fisheries Science, Rhodes University, Grahamstown, 117pp.

Singh, V. K., Chauhan, S. S., Ravikanth, K., Maini, S., Rekhe, D.S. (2009): Effect of dietary supplementation of polyherbal liver stimulant on growth performance and nutrient utilization in broiler chicken. Veterinary World, 2, 350 - 352

Shipton, T., Britz, P. J. (2007): A Study on the Status of Aqua- culture Production and Trade in South Africa. Volume 1: Industry Status and Diagnostic Report. A report for the Department of Trade and Industry produced by EnviroFish Africa (Pty), Ltd. 90pp.

Troell, M., Robertson-Andersson, D., Anderson, R.J., Bolton, J. J., Maneveldt, G., Halling, C., Probyn, T. (2006): Abalone farming in South Africa: An overview with perspectives on kelp resources, abalone feed, potential for on-farm seaweed production and socio-economic importance. Aquaculture, 257, 266 - 281.

Trushenski, J. T., Kasper, C. S., Kohler, C. C. (2006): Challenges and opportunities in finfish nutrition. North American Journal of Aquaculture, 68, 122 - 140.

Woolley, L. D., Jones, C. L. W., Britz, P.J. (2009): The development of a practical diet for juvenile dusky kob Argyrosomus japonicas, for the South African mariculture industry. M.Sc. thesis, Department of Ichthyology and Fisheries Science, Rhodes University, Grahamstown. 77p. 